\title{
Oral Contract on the Sale and Purchase Transactions in the Traditional Market of Palangka Raya City
}

\author{
Muzalifah ${ }^{1}$, Ali Sodiqin ${ }^{2}$ \\ IAIN Palangkaraya ${ }^{1}$, UIN Sunan Kalijaga Yogyakarta ${ }^{2}$ \\ e-mail: muzalifah@iain-palangkaraya.ac.id ${ }^{1}$, ali.sodiqin@uin-suka.ac.id ${ }^{2}$
}

\begin{abstract}
The application of an oral contract in buying and selling transactions in Palangka Raya City is a form of contract adopted from Banjar culture. Even traditional market players in Palangka Raya City, in particular, interpret the oral contract as something that is very principle, so that they consider a contract invalid if it is not stated verbally. This article explores the question of why the oral contract in buying and selling in Palangka Raya City is still being applied and how the oral contract law is in buying and selling transactions in Palangka Raya City. This research is qualitative research with a phenomenological approach. This study found that the application of oral contracts in buying and selling transactions in Palangka Raya City originated from the habits of Banjar tribe traders who trade in Palangka Raya City. This habit, then, develops into the habit of the local community, so it becomes a necessity to be implemented. The law of the oral contract in the transaction is valid in terms of Islamic law and civil law because it fulfills the requirements and is in harmony with the contract in buying and selling and is carried out voluntarily, is based on the principle of freedom of contract. There is a balance of achievement, and has legal certainty so that it binds both parties. The existence of this oral contract shows the legitimacy of legal norms, religious norms, and customary norms.
\end{abstract}

Keyword: oral contract, buying and selling, Islamic law, civil law, Banjar tribe.

\begin{abstract}
Abstrak
Penerapan akad lisan dalam transaksi jual beli di Kota Palangka Raya merupakan salah satu bentuk akad yang diadopsi dari budaya Banjar. Bahkan pelaku pasar tradisional di Kota Palangka Raya khususnya, memaknai akad lisan sebagai sesuatu yang sangat prinsip, sehingga menganggap tidak sah
\end{abstract}


suatu akad jika tidak dinyatakan dengan lisan. Artikel ini mengeksplorasi pertanyaan mengapa akad lisan dalam jual beli di Kota Palangka Raya masih diterapkan dan bagaimana hukum akad lisan pada transaksi jual beli di Kota Palangka Raya. Penelitian ini merupakan penelitian kualitatif dengan pendekatan fenomenologi. Penelitian ini menemukan bahwa penerapan akad lisan dalam transaksi jual beli di Kota Palangka Raya berawal dari kebiasaan pedagang suku Banjar yang berdagang di Kota Palangka Raya. Kebiasaan tersebut kemudian berkembang menjadi kebiasaan masyarakat setempat, sehingga menjadi suatu keharusan untuk dilaksanakan. Hukum akad lisan pada transaksi tersebut adalah sah dari sisi hukum Islam maupun hukum perdata karena memenuhi syarat dan rukun akad dalam jual beli serta dilakukan dengan sukarela, didasarkan pada asas kebebasan berkontrak, adanya keseimbangan prestasi, dan memiliki kepastian hokum sehingga mengikat kedua beah pihak. Keberadaan akad lisan ini menunjukkan adanya legitimasi dari norma hukum, norma agama, dan norma adat.

Kata Kunci: akad lisan, jual beli, hukum Islam, hukum perdata, suku Banjar

\section{INTRODUCTION}

The economic development of Palangka Raya City cannot be separated from the influence of capitalization, as has happened in other cities in Indonesia. This influence has had a significant impact on the development of modern shops, but on the other hand, has harmed traditional markets. This phenomenon does not only occur in Palangka Raya City but also other cities in Indonesia, such as Madiun, Makassar, Surakarta, Medan, Padang, and Surabaya. The statement is based on the results of research conducted by Dakhoir (2018); Masyhuri \& Utomo , 2017; et al., 2017; Handoyo, 2016; Fajriawati, 2018; Effendi, 2017; Noor, 2017; dan Wahab, 2016.

The above studies conclude that the existence of modern markets harms the existence of traditional markets. Nevertheless, the presence of modern markets does not necessarily change the traditions and culture that have become icons of traditional markets, especially in Palangka Raya City. In the case of buying and selling transactions, for example, the implementation of sale and purchase contracts at traditional markets in Palangka Raya City is not 
contaminated by contract traditions in modern markets. The community continues to carry out transactions with oral traditions, both at the time of bargaining and in implementing the sale and purchase contract.

The difference between buying and selling transactions between traditional and modern markets lies in the process alone. In the modern market, there is no longer a bargaining process, because every item sold already has a price tag. Meanwhile, in traditional markets, there is still bargaining in the transaction process. In both traditional and modern markets, the contract in buying and selling is carried out without uttering a verbal contract either by the seller or by the buyer. The form of handing over of goods is carried out by the buyer giving an amount of money for the price of the goods purchased to the seller, then the seller receives the money in exchange for the price of the goods without pronouncing a verbal contract.

The discussion about the contract or agreement in positive law and Islamic law has been widely studied by previous researchers, such as Haryanto (2010); Indirahati (2014); Sugiastuti (2016); Hanafiah (2015); and Sukardi (2017). From some of these research results, it can be concluded that the contract is a law that can bind several parties involved in the contract, both standard and oral contracts. Besides, some of the researchers also discussed the oral tradition in the sale and purchase agreement, but still struggled with the issue of legal validity only and had not touched on the aspects of merchant culture that influenced the application of the oral contract in the sale and purchase transaction, as happened in the Palangka Raya City.

Apart from the economic side, market development in Palangka Raya City is also influenced by the traditions and culture that build the market system. One of them is the oral tradition in the sale and purchase contract which is always carried out by traders at the end of the transaction process. This phenomenon can be witnessed in trade transactions that are generally carried out by traditional market players. In this case, at the end of the sale and purchase transaction, the seller and the buyer will say ijab and qabul at one time and face each other, usually accompanied by a handshake between the seller and the buyer. For example, the ijab statement is "ulun jual (I sell)", while the qabul is "ulun tukar (I buy)". Oral traditions in the application of buying and selling contracts like this show that this phenomenon is part of the law that occurs in everyday life in the people of Palangka Raya City. 


\section{Fitrah \\ Jurnal Kajian Ilmu-ilmu Keislaman \\ Vol. 6 No. 2 December 2020}

The oral contract through the ijab qabul indicates the influence of Islamic teachings. This Islamic aspect is shown by traditional market players in the form of an oral contract in buying and selling transactions. This explains the desire of the people of Palangka Raya City to show their religious identity, namely Islam (Klinken Van \& Berenschot, 2014:180). The people of Palangka Raya City in this case interpret the contract as something very principle, so they consider a transaction invalid if it is not stated with a clear contract (Hanafiah 2015:204).

The implementation of oral contracts in buying and selling generally occurs in traditional markets and the perpetrators are mostly people or the Banjar tribe. The Banjar tribe is an ethnic group who mostly live in the South Kalimantan Province. Historically, the Banjar tribe has occupied parts of Central Kalimantan around the 17th century, including in Palangka Raya City (Hanafiah, 2015:210). Their presence spreads to various fields of life, including economics and trade. So that the culture of the Banjar Tribe colors the economic tradition in Palangka Raya City, including the tradition of oral contracts in buying and selling transactions.

The focus of this article is to explore why the people of Palangka Raya City still use oral contracts in buying and selling in traditional markets. This question reveals the factors behind the persistence of this oral contract and which community groups are its supporters. Besides, this article also explains how the oral contract law in buying and selling transactions in Palangka Raya City from the perspective of Islamic law and Indonesian civil law. The aim is to analyze the legality of the oral contract from the perspective of religious law and positive law.

The discussion in this article has both theoretical and practical urgency. Theoretically, the existence of an oral contract in society today shows that traditional understanding is still maintained in the realm of modernity, which has changed the economic transaction system a lot. The use of oral contracts can be seen as a strategy for the resilience of a society in its cultural identity. In practical terms, this research provides input to academics and is friendly to explore local treasures related to traditional economic systems.

\section{RESEARCH METHOD}

This research is descriptive qualitative research with a phenomenological approach by taking the object of the study of traditional markets in Palangka 
Raya City. The phenomenological approach is used to explain the phenomenon that occurs in buying and selling transactions using oral contracts between sellers and buyers in Palangka Raya City in their daily lives. The research data were collected through participant observation techniques in traditional markets in Palangka Raya City, such as Kahayan Market and Datah Manuah Market. Apart from observations, interviews were also conducted with traders and buyers to explore the results of observations. Besides, this research also uses literature review, by collecting documents, in the form of books, articles, and research results. The initial method of instruction is to analyze how the oral contract law in buying and selling transactions in the traditional markets of Palangka Raya City from the perspective of Islamic law and positive law references relevant to this research.

\section{RESEARCH FINDINGS AND DISCUSSION}

Every business activity in Islam must be carried out under a valid contract ('aqd). 'Aqd is a legal contract in the form of action that can be enforced with a bilateral statement, namely offer and acceptance (Soemitra 2016). The bilateral declaration in question is the contract pronounced by the seller and buyer when making a sale and purchase transaction. As for the theory of the contract or agreement, besides being contained in Islamic law, it is also contained in positive law (Indonesian Civil Code). In positive law, the contract can also be referred to as an agreement. On the other hand, the implementation of the contract is also closely related to 'urf (custom) which has become a local custom and has even been institutionalized into customary law. Therefore, it is important to explain the theoretical framework of contract law in the Civil Code and Islamic law as the basis for analysis in this paper.

\section{Agreement law according to the Civil Code}

Agreement law in the context of Western law is regulated in the provisions of Book III of the Civil code on the engagement. Article 1313 of the Civil Code remembers that an agreement is a legal event that occurs when a person or more binds himself to someone or more. A legal agreement that fulfills the legal requirements of an agreement is contained in Article 1320 of the Civil Code, which is an agreement between the parties, is legally competent, some objects exist, and for lawful reasons (Anshori, 2010: 7). Besides, the provisions of Article 1330 of the Civil Code also pertain to persons who are incapable by law, 
namely: children who are still minors, people who have lost memory (under interdiction), extravagant people, and wives of spouses who are subject to Civil Code. The object of the agreement must be certain and/or at least can be determined. Apart from that, everything that becomes the object of the agreement must not be contrary to law, decency, or public order in force in society. An agreement that is prohibited from being made without cause, including all false or prohibited causes. If one of the conditions is not met, the agreement can be canceled by mutual agreement or null and void. Juridically, a legal agreement can be binding on the parties like law, so it must be implemented in good faith and one cannot decide an agreement without the agreement of the two parties (Anshori, 2010: 7-8).

The concept of contract law according to the Civil Code adheres to various principles, namely the principle of freedom of contract, the principle of personality, and the principle of good faith. The principle of freedom of contract/laissez-faire is contained in Article 1338 of the Civil Code, namely: "All agreements are made legally as law for those who make them". However, there is a limit to the freedom of contract, because it is logical that the parties are prohibited from entering into agreements that are contrary to propriety, custom, and law. In the context of the Civil Code, agreement law is complementary law (aanvulend recht) which can be stated from Article 1339 of the Civil Code which states that agreements are not only binding on matters expressly stated in them but also for everything that according to the nature of the agreement is required by appropriateness, custom or law.

The personality principle is stated in the provisions of Article 1340 of the Civil Code. The principle of personality as one of the principles in an agreement has exceptions as written in the provisions of Article 1317 of the Civil Code, namely that a promise for the benefit of a third party is actually giving or giving up his rights to a third party. A statement of good faith in the provisions of Article 1338 of the Civil Code, which states that every legal agreement must be carried out by the parties who entered into it in good faith. This doctrine of good faith is an essential doctrine of a treaty that has been known for a long time with the principle of pacta sunt servanda (Anshori, 2010: 8-10).

\section{Islamic Treaty Law in Indonesia}

In the history of law in Indonesia, between Islamic law and customary law, there is a very close relationship. This can be seen in various legal theories 
concerning the problem of the application of Islamic law in Indonesia. There are three kinds of legal theories regarding this matter, namely: receptio in complexu theory, receptie theory, and receptie a contrario theory. Receptio theory in complex statements that Islamic law has been accepted as a whole and is used as a reference for legal problems that exist in Islamic society. The theory of acceptance was introduced by Cornelis van Vollenhoven (1874-1933) and developed by Christian Snouck Hurgronje (1857-1936) a Dutch East Indies government on issues of Islam and the Children of the Colonies. The essence of this theory is that the laws that apply to Muslims are their respective customary laws, and the new Islamic law that has come into effect has been accepted or accepted by customary law. Thus, it is a customary law that determines the application of Islamic law. The theory of receptie a contrario, which is a theory that is a rebuttal to the second theory, that in practice it is not customary law that is the basis for the application of Islamic law (Wahyuni, 2014: 89-90). The application of customary law among Muslims is because the customary law is not against Islamic law, and includes urf which is one of the sources of law recognized by Islam (Anshori, 2010: 14-16).

In Islamic Civil Law, several legal principles become the foundation or foundation for protecting one's personal interests (Anshori, 2010: 18-21). These principles include: (1) the principle of permitted or permissible, (2) the principle of the benefit of life, (3) the principle of freedom and volunteerism, (4) the principle of rejecting harm and taking advantage, (5) the principle of virtue (), (6) the principle of kinship or the principle of equal togetherness, (7) the principle of fairness and balance, (8) the principle of prioritizing obligation of rights, (9) as a prohibition that harms oneself and others, (10) the principle of ability and action, as the freedom to do business, (11) as the freedom to do business, as a protection effort, as a right of protection, as a right that functions as a right that social function, (12) the principle of good faith must be protected, the principle of risk being imposed on assets (not on workers), (13) the principle of imposing and giving directions, and (14) the principle of being written or pronounced in front of a statement.

\section{Contract according to Islamic law}

The contract comes from the Arabic 'aqd, which means a bond or conclusion, both visible (hissyy) and invisible (ma'nawy) ties. In al-Mawrid's dictionary, the word al-'aqd is translated as contract and agreement. Meanwhile, according to Muhammad Salam Madzkur, a contract according to the term is an 
agreement or joint commitment, whether oral, gesture or written between two or more parties that have binding legal implications to carry it out. Subhi Mahmasani also defines a contract as a bond or relationship between ijab and qabul which has legal consequences for things that are contracted (Yulianti, 2008: 93).

Syamsul Anwar stated that in Islamic law the term contract is not distinguished from an agreement, both are identical and are called a contract. So in this case the contract is defined as a meeting of ijab declared by one party with the qabul from the other party legally according to syara' which appears as a legal effect on the object. Thus it can be said that the contract is a mutual agreement, either verbal, gesture, or in writing between two or more parties through consent and qabul which has legal ties for all parties involved to carry out what is the agreement (Yulianti, 2008: 94).

Nasrun Harun in Komari, states that an agreement in Islamic law is known as al-'aqd which means an agreement, an agreement of consensus. In fiqh terminology, the contract is defined as the relationship between ijab (statement of making a bond) and qabul (statement of accepting a bond) following the will of the Shari'a which affects the object of the engagement. The inclusion of the sentence "with the will of the Shari'a" means that all agreements carried out by two or more parties are not following the will by the will of the Shari'a. For example, an agreement to make usury transactions, cheat others, or rob someone else's wealth, then are illegal dating. While the inclusion of the sentence "affects the object of the engagement" means that there is a movement of the owner/rights from one party (who makes ijab) to another party who performs qabul (Komari, 2017: 73).

Agreement law or contract is part of private law. This law focuses on the obligation to carry out yourself or self-imposed obligation (Novi Ratna Sari 2017). Therefore, a contract or agreement becomes valid and legally binding for the party making it. An oral contract in a sale and purchase transaction is valid according to positive law, the conditions for fulfilling a person's legal requirements as regulated in Article 1320 of the Civil Code. Article 1320 determines four conditions for the validity of the agreement, namely: 1) There is the ability to make an engagement (bekwaamheid); 2) There is a license as an agreement by those who promise (toestemming); 3) Regarding a certain thing or object (bepaalde onderwerp), and 4) There is a justified cause (georloofde oorzak). 
The implementation of an oral contract in a sale and purchase transaction can minimize any defects in the contract. Defects in the contract in Islamic jurisprudence are things that damage the contract because the voluntary elements between the affected parties are not fulfilled. Matters that are deemed bad to damage the contract, including non-fulfillment of the terms and harmony of the contract, incidents of coercion, mistakes, fraud or forgery, and deception (Alia, 2015: 2). Regarding the object of the contract, the scholars believe that the status of the sale and purchase contract whose goods are defective and invalid by the seller is legal, but the seller is a sinner. This is based on the words of the Prophet Muhammad SAW, "Do not do tashriyah (let the livestock that is breastfeeding not be milked so that they seem to have a lot of milk when they are sold)" (Alia, 2015: 8).

The principle of an oral contract in buying and selling transactions in Palangka Raya City

According to the Large Dictionary Indonesian, the principle comes from the Arabic asasun which means basis or foundation. In terminology, the principle is the basis or something on which to think or argue. The word principle, when connected with the word 'law', has the meaning of truth which is used as a basis for thinking and reasons for the opinion, especially in law enforcement and implementation. From this definition, if it is related to contract law in buying and selling, the principle is the truth that is used as a basis for thinking and reasons for arguing about the contract, especially in enforcing and implementing the sale and purchase contract (Anwar, 2010: 96).

In the sale and purchase agreement, there are agreement principles that underlie its enforcement and implementation. The agreement principles are classified into agreement principles that do not have legal consequences and are general in nature and contractual principles that have legal consequences and are of a special nature. As for the principles of the agreement which have legal consequences and are general in nature, are as follows: first, the Ilahiah principle or the principle of Tawhid. Every human behavior and deed does not escape the provisions of Allah SWT as mentioned in QS. Al-Hadid (57:4). Second, the principle of permissibility (mabda al-ibahah) is based on the principle of fighiyah which means: "in principle, everything is allowed until there are arguments against it". Third, the principle of justice (al-'adalah), is contained in QS. Al-Hadid 


\section{Fitrah \\ Jurnal Kajian Ilmu-ilmu Keislaman \\ Vol. 6 No. 2 December 2020}

(57): 25 and QS. Al-A'raf (7): 29. Fourth, the principle of equality and equation is contained in QS. Al-Hujarat (49): 13; fifth, the principle of honesty and truth (ash shidiq), is contained in QS. Al-Ahzab (33): 70 ; sixth, the principle of writing (al kitabah), is contained in QS. Al-Baqarah (2) 282-283; seventh, the principle of good faith (the principle of trust) which can be equated with the provisions in Article 1338 of the Civil Code; and eight, the principle of benefit and maslahah (Anwar, 2010: 97-99).

Meanwhile, the principles which have legal consequences and are of a special nature are: first, the principle of consensual or the principle of willingness (mabda 'ar-rada'iyyah), contained in QS. An-Nisa (4):29 and Article 1320 verse (1) of the Civil Code; second, like freedom of contract (mabda 'hurriyah at-ta'aqud), contained in QS. Al-Maidah (5): 1; third, the principle of a binding agreement; fourth, the principle of balance of achievement, namely the principle that requires both parties to fulfill and carry out the agreement; Fifth, the principle of legal certainty (pacta sunt servanda), contained in QS. Bani Israil (17):15; sixth, the principle of personality, the provisions in this principle can be understood from Articles 1315 and 1340 of the Civil Code; and seventh, the principle of freedom of contract (Yulianti, 2008: 100-102).

Based on the explanation above, the implementation of oral contracts in buying and selling transactions in Palangka Raya City has fulfilled general and specific principles as stated in positive law and Islamic law. Verbal buying and selling transactions fulfill Ilahiah principles, virtue, fairness, equality, honesty and truth, good faith, as well as benefit and maslahah. In carrying out this contract, the seller and buyer have equality, honesty, and good faith. The ijab statement from the seller which is connected with the qabul from the buyer indicates the fulfillment of this principle. The oral contract also shows the fulfillment of the principle of permissibility and justice, because legally, both Islamic law and positive law, there is no prohibition on oral buying and selling.

From the perspective of a special principle, verbal trading also implies a willingness and balance of achievement between the seller and the buyer. Basically, both parties have the freedom to contract, including the freedom to determine the model of the contract to be carried out. By pronouncing the ijab and qabul from both parties, the transaction is binding and has legal certainty. 
Goods that have been sold legally belong to the buyer, likewise the money given by the buyer also legally belongs to the seller.

The acceptance of the concept of an oral contract in everyday life in Palangka Raya City shows that the transaction has become the local wisdom of the area. In this transaction, there is a harmonization of the relationship between the seller and the buyer through a bargaining process. When the two parties agree on the price of the goods being sold and bought, the buyer's qabul is a statement of agreement that binds both parties (Nasrullah 2016). This shows that the legitimacy and validity of this oral contract conform to legal norms, religious norms, and customary norms. The people of Palangka Raya City, which are predominantly Muslim, uphold their religious teachings so that they form a culture that becomes a guide in their daily life.

Pillars and terms of the oral contract in buying and selling transactions in Palangka Raya City

The types and forms of agreements are divided into various depending on the point of view used. Among the points of view that give rise to different types and forms of agreement are: 1) in terms of formation, the agreement sometimes takes the form of an agreement rida'i, syakli, and 'ayni; 2 ) in terms of its object, the agreement is divided into a musamma agreement, ghayru musamma agreement, and sometimes in the form of a basit and mukhtalit agreement; 3) in terms of effect, the agreement sometimes takes the form of a dhati agreement, ittifaq munazzam sometimes binds two parties or is unilateral, and there is also a mu'awadah or tabarru' agreement; and 4) in terms of their nature, there are agreements that are muhaddad or ihtimali, sometimes in the form of fawri or musramir agreements, and sometimes in the form of original agreements or thaba'i (Fauzi, 2016: 37-38).

An agreement is declared valid if certain elements contain predetermined criteria. These provisions are often referred to as terms and conditions. The main elements that must be in an agreement are: 1) al-aqid/al muta'aqidayn (the person who agreed); 2) sighat (something that shows the willingness to do the agreement from the covenant actors); 3) mahall al'-aqd/ma'qul alayh (matters that have legal and effect from the agreement); and 4) maudu' al-'aqd (the core purpose of implementing the agreement) (Fauzi, 2016: 38). 


\section{Fitrah \\ Jurnal Kajian Ilmu-ilmu Keislaman \\ Vol. 6 No. 2 December 2020}

Based on the explanation, the oral sale and purchase contract that occurred in Palangka Raya City had fulfilled the pillars and elements in a contract. In this transaction, there are legal subjects, namely sellers and buyers who pronounce the contract verbally, it is done voluntarily and there are objectives to be achieved in implementing the contract, namely buying and selling. Thus, the contract is valid both in terms of positive law and Islamic law.

Each of the aforementioned main elements also meets certain requirements so that an agreement is created that follows Islamic principles. These conditions are in the form of general conditions, which must be fulfilled in any agreement of any kind and form, and some are in the form of special conditions, which only have to be in some agreements and not in other agreements. In the Hanafi sect of thought, there is only one pillar of the sale and purchase agreement, namely sighat in the form of an ijab-qabul, while the sale and purchase agreement must meet several conditions (syara'it al-in'iqad). These conditions also differ depending on al-'aqid, al-'aqd, makan al-'aqd, or ma'qud 'alayh (Fauzi, 2016: 39-40).

Unlike the Hanafi sect, the pillar agreement, including buying and selling transactions of the Shafi'i sect, apart from sighat, must also have al-aqid, and $m a^{\prime} q u l$ alayh. Each pillar must also meet certain conditions. For example, there must be compatibility between ijab and qabul, ma'qud alayh must be useful, pure, can be handed over. Meanwhile, al-'aqid must be rasyid (adult), have the freedom between canceling and continuing the agreement, have power, either with ownership rights, territory, or give permission, and must know the conditions of $m a^{\prime} q u d$ alayh. Meanwhile, al-Sanhury after stating the pillars of agreement in French civil law which includes four types; ridha, expertise, mahall, and sabab, finally also consider ridha as the only pillar of the agreement. According to him, expertise is only a condition for being ridha, not as a pillar that stands alone. Meanwhile, mahalli and sabab are not pillars of the agreement but pillars of engagement (Fauzi, 2016: 41-42).

\section{Oral contract law on buying and selling transactions in Palangka Raya City}

Based on the researcher's observation, Palangka Raya City is a part of Indonesia that is famous for its friendliness. This is also embedded in the buying and selling transactions carried out by traditional traders in particular. In 
practice, they will greet each other when they meet fellow traders or buyers. The habit of "suka negur" has an impact on the spoken language that is often spoken by traders when they are about to carry out contracts in buying and selling.

From generation to generation, the Indonesian people are indigenous peoples who generally have an oral or oral tradition including in Palangka Raya City. Oral traditions, oral culture, and oral customs in a sale and purchase agreement, for example, are messages or testimonies that are passed down from generation to generation and from one generation to the next. The message or testimony can also be conveyed through utterances, speeches, chants, and can take the form of poetry, folk tales, advice, ballads, or songs. In this way, a society can deliver oral literature, oral law, and other knowledge to future generations without involving written language in their daily lives (Sugiastuti, 2016: 38).

In a city with an oral tradition such as Palangka Raya City, traders usually do not appreciate the written tradition as a form of realization of the existence of the oral tradition. They think that writing is only considered as a means of documentation. If connected with the context of the agreement/contract, a written contract is considered a mere condition, the contract only fulfills its meaning textually but not contextually (Sugiastuti, 2016: 40). Besides, the spoken language in implementing the sale and purchase contract in Palangka Raya City can also be said to only be a symbol of Islam, where the culture of traders or business people also plays a role in coloring the oral contract process. In principle, in the conception of the legal system, it is stated that the legal culture of society will influence the implementation of the law itself. The law can die because society does not accept it because it is considered not part of the norm that must be obeyed (Sugiastuti, 2016: 31).

In Islamic law, there are at least two terms of the agreement, namely the word contract (al-'aqdu) and word 'ahd (al-'ahdu), contract or al-'aqdu in Arabic means a knot, or agreement and deal. The word 'aqdu (or al'aqd) itself refers to the occurrence of two or more agreements, that is, if someone makes an appointment then someone else agrees to the promise and states a promise related to the first promise so that there is an agreement between two promises from someone who has a relationship with each other, which is then called an agreement ('aqd)) (Novi Ratna Sari, 2017: 81). The formulation of the contract 


\section{Fitrah \\ Jurnal Kajian Ilmu-ilmu Keislaman \\ Vol. 6 No. 2 December 2020}

above indicates that the agreement must be an agreement between the two parties as practiced in the sale and purchase contract process in everyday life in Palangka Raya City. The purpose of the contract is to knot with each other about the actions that will be carried out in a special case after the contract is effectively enforced. As for the terms of the validity of the agreement or contract, they are: 1) The existence of the subject of the Engagement (Al'Aqidin); 2) The existence of the engagement object (Mahallul 'Aqd); 3) The purpose of the engagement (Maudhu ' $u l^{\prime} A q d$ ); and 4) Ijab and qabul (Sighat al-'Aqd). It should also be noted that contracts or agreements (overeenkoms) in positive law (Civil Law) are derived from Roman law (Roman Law), while contracts or agreements in Islamic law originate from the Al-Quran and Hadith, some even come from Ijma 'and Qiyas (Anwar, 2010: 47).

Legal subjects who carry out the sale and purchase contract in Palangka Raya City can be said to be competent in terms of positive law and Islamic law, which is generally carried out by adults. The "Skills in Making Agreements" contained between the contract in the Civil Code and Islamic law is that the basis of that propriety is "reasoned" and therefore some of these skills are imperfect and some are perfect. Thus, the content of Article 1320 verse (1) of the Indonesian Civil Code is in line with the principles of Islamic law. However, what distinguishes it is that in the Civil Code the measure of maturity is 21 years of age and/or already married, while in Islamic law it is baligh where someone has had a wet dream (ihtilam) for men and has menstruation for women.

A contract in a sale and purchase transaction in Palangka Raya City can occur if there is an agreement between the two parties. Regarding "there is an agreement (toesteming / permission) of both parties", between the Civil Code and Islamic law lies in the validity of an agreement. In both the Civil Code and Islamic Law an agreement is declared invalid if the agreement reached occurs because of an error or was made using of coercion or fraud. Meanwhile, what distinguishes it is that in the Civil Code, many parties have made statements of intentions, namely in perfect language orally and writing. Whereas in Islamic law agreement is usually expressed in the words Ijab and qabul (Sighat al-'Aqd).

As for the object of the contract in the sale and purchase transaction in Palangka Raya City, the merchant will show the object of the contract directly, 
and at that time the buyer can see carefully the goods being sold. Therefore, it is unlikely that there will be contract defects because the object of the contract is what the buyer wants. Regarding the terms "there is an object of agreement (onderwerp der overreenskomst)", the object of the agreement in both the Civil Code and Islamic Law requires that every contract must be about something like a legal object. Meanwhile, what distinguishes it is that in the Civil Code, it is stated that the object of the agreement is the achievement (the principal of the agreement) which must be determined, permitted, possible, and can be valued in money. Whereas in Islamic law something that is used as the object of the contract (Mahallul 'Aqd) the object of the engagement already exists when the contract is carried out, it is confirmed by sharia, the object must be clearly recognized, and the object must be able to be handed over.

The system which has always been rooted has even become law in daily life in Palangka Raya City, especially in the process of buying and selling transactions orally is part of local wisdom. In its implementation, it is based on halal causes both in terms of positive law and Islamic law. Halal causes (geoorloofde oorzaak) in the terms of the contract, namely when the agreement requires good faith from the parties in making the contract, therefore the contract caused by something that is not lawful, for example, due to coercion or trickery does not meet the requirements, both in the Civil Code and Islamic law is considered null and void.

\section{CONCLUSION}

The role of oral tradition in the buying and selling contract process has the potential to be used to strengthen cultural resilience in Palangka Raya City. The oral tradition of buying and selling is part of the culture in Palangka Raya City which was passed down from generation to generation orally as a form of similarity of property and collective ideas that are generally carried out by traders from the Banjar tribe in Palangka Raya City. As for whether or not the oral contract law is valid for buying and selling transactions carried out by traders in Palangka Raya City, it cannot be separated from the legal basis and the history of oral traditions that shape the law and daily life in Palangka Raya City. The legal foundation is in positive law and Islamic law. In positive law, oral contracts in buying and selling transactions in everyday life are valid because 


\section{Fitrah \\ $\triangle$ Jurnal Kajian Ilmu-ilmu Keislaman \\ Vol. 6 No. 2 December 2020}

they are in line with Article 1320 of the Civil Code. Whereas in Islamic law, an oral contract in such a transaction is valid because it fulfills the terms and conditions of a contract based on the Quran and Hadith, as well as from the opinions of several scholars whose thoughts are based on Islamic law. 


\section{REFERENCES}

Alia, Cut Lika. 2015. “Akad Yang Cacat Dalam Hukum Perjanjian Islam.” Premis Law Jurnal 2:1-17.

Anshori, Abdul Ghofur. 2010. Hukum Perjanjian Islam Di Indonesia: Konsep, Regulasi, Dan Implementasi. Yogyakarta: Ghajah Mada University Press.

Anwar, Syamsul. 2010. Hukum Perjanjian Syariah: Studi Tentang Teori Akad Dalam Fikih Muamalah. Jakarta: PT Raja Grapindo Persada.

Dakhoir, Ahmad. 2018. “Eksistensi Usaha Kecil Menengah Dan Pasar Tradisional Dalam Kebijakan Pengembangan Pasar Modern." Jurnal Studi Agama Dan Masyarakat 14(1):31-41. doi: 10.23971/jsam.v14i1.783.

Effendi, Nursyirwan-. 2017. "Studi Budaya Pasar Tradisional Dan Perubahan Gaya Hidup Masyarakat Pedesaan: Kasus Pasa Nagari Dan Masyarakat Nagari Di Propinsi Sumatera Barat." Jurnal Antropologi: Isu-Isu Sosial Budaya 18(2):105. doi: 10.25077/jantro.v18.n2.p105-120.2016.

Fajriawati, Fajriawati. 2018. "Analisis Pengaruh Persaingan Usaha Pasar Tradisional Terhadap Pasar Modern Peraturan Daerah Kota Medan." Varia Justicia 13(2):103-11. doi: 10.31603/variajusticia.v13i2.1884.

Fauzi, Moh. 2016. “Perikatan Dan Perjanjian Dalam Hukum Islam.” At-Taqaddum 3(1).

Hanafiah, HM. 2015. “Akad Jual Beli Dalam Tradisi Pasar Terapung Masyarakat Banjar." Al-Tahrir: Jurnal Pemikiran Islam 15(1):201. doi: 10.21154/altahrir.v15i1.170.

Handoyo, Handoyo. 2017. "Perlindungan Hukum Pasar Tradisional Di Surakarta." Jurnal Jurisprudence 6(1):40. doi: 10.23917/jurisprudence.v6i1.2997.

Haryanto, Totok Dwinur. 2010. “Hubungan Hukum Yang Menimbulkan Hak Dan Kewajiban Dalam Kontrak Bisnis." Wacana Hukum IX(1):85-97.

Indiraharti, Novina Sri. 2014. "Aspek Keabsahan Perjanjian Dalam Hukum Kontrak (Suatu Perbandingan Antara Indonesia Dan Korea Selatan)." Jurnal Hukum PRIORIS 4(1):15-38.

Klinken van, G., and W. Berenschot. 2014. In Search of Middle Indonesia.

KOMARI. 2017. "Hukum Perjanjian Dan Akad Transaksi Syariah Di Indonesia (Tujuh Indikator Keberhasilan Dan Kegagalan Dalam Kacamata Islam)." Eksyar 04(1):70-81.

Masyhuri, Mahmudah, and Supri Wahyudi Utomo. 2017. "Analisis Dampak 


\section{Fitrah}

Jurnal Kajian Ilmu-ilmu Keislaman

Vol. 6 No. 2 December 2020

Keberadaan Pasar Modern Terhadap Pasar Tradisional Sleko Di Kota Madiun." Assets: Jurnal Akuntansi Dan Pendidikan. doi: 10.25273/jap.v6i1.1293.

Nasrullah. 2016. “Jual Seadanya; Telaah Antropologis Terhadap Implementasi Ajaran Islam Dalam Akad Jual Beli Pada Orang Banjar." Pp. 1-15 in Transformasi Sosial dan Intelektual Orang Banjar Kontemporer. Banjarmasin: IAIN Antasari Banjarmasin.

Noor, Triana Rosalina. 2017. “Fungsi Sosial-Ekonomi Pasar Tradisional (Studi Tentang Pasar Karah, Kec. Jambangan, Kota Surabaya)." Manajemen Pendidikan Islam STAI An Najah Indonesia Mandiri.

Novi Ratna Sari. 2017. “Komparasi Syarat Sahnya Perjanjian Menurut Kitab Undang-Undang Hukum Perdata Dan Hukum Islam." Repertorium 4(2).

Soemitra, Andri. 2016. "Higher Objectives of Islamic Investment Products: Islamizing Indonesian Capital Market." Studia Islamika.

Sugiastuti, N. Y. 2016. "Esensi Kontrak Sebagai Hukum Vs Budaya Masyarakat Indonesia Yang Non-Law Minded Dan Berbasis Oral Tradition." Jurnal Hukum PRIORIS 5(1):31-44.

Sukardi, Sukardi. 2017. “Kebebasan Berkontrak Dalam Jual Beli Menurut Kitab Undang-Undang HUkum Perdata Dan Kompilasi Hukum Ekonomi Syariah." Al-Maslahah Jurnal Ilmu Syariah 12(2):405. doi: 10.24260/almaslahah.v12i2.408.

Wahab, Abdul. 2016. "Keberpihakan Kebijakan Pemerintah Pada Sektor Usaha Rakyat Perspektif Ekonomi Islam (Studi Kasus Keberlangsungan Pasar Tradisional)." TSAQAFAH 12(1):167. doi: 10.21111/tsaqafah.v12i1.373.

Wahyuni, Sri. 2014. Politik Hukum Islam Pasca Orde Baru. Yogyakarta: GapuraPublising.Com.

Wasilah, Wasilah, St. Aisyah Rahman, and Muhammad Misbahuddin. 2017. "Pasar Tradisional Dengan Penataan Modern Di Kota Makassar." Nature: National Academic Journal of Architecture 4(1):11-20. doi: 10.24252/nature.v4i1a2.

Yulianti, Rahmani Timorita. 2008. “Asas-Asas Perjanjian (Akad) Dalam Hukum Kontrak Syari'ah.” La_Riba II(1):91-107. doi: 10.20885/lariba.vol2.iss1.art7. 